\title{
Fifty Years of British Music Video
}

\section{Introduction}

\section{EMILY CASTON AND JUSTIN SMITH}

The dedicated scholarship on music video has been dominated by US perspectives, just as popular perceptions of the medium have been shaped by MTV. Yet the British story followed its own arc: its talent educated at art schools, its industry differently organised and its shop windows until the arrival of MTV Europe in 1987 - represented primarily by Top of the Pops (BBC, 1964-2006) and The Chart Show (Channel 4 \& ITV, 1986-1998). This special issue features new research which explores aspects of music video culture in the UK for the first time, and adopts fresh approaches to its analysis. The contributors are members of the Arts and Humanities Research Council-funded 'Fifty Years of British Music Video' project team, and their partners at the British Film Institute (BFI) who will curate a 'British Landmark Video' collection as one of the project's key archival outputs.

The project was designed as a collaboration between a number of public and private stakeholders including the British Library, the BFI, Warp Records (a major UK independent record label), Thunderbird Releasing (a film distributor), and Video Performance Ltd (the licensing agency for the British recording industry). It was conceived from the outset as a collaboration with the British music video industry as a joint intellectual effort. This industry focus is a distinctive aspect of the project's intellectual work, and is demonstrated in the articles gathered in this special issue.

Music video is one of a number of 'hidden' screen industries that had been neglected in government-funded creative industries research (e.g. Hutton et al., 2007) and, apart from Emily Caston's own research nothing has been published on the industry or its contribution to the British creative economy (Caston et al., 2000). The whereabouts of most video masters was unknown, and the collections of significant recording artists, video directors, and production companies had never been curated 
in any publicly accessible form, let alone put into a systemic catalogue that would enable academic analysis in pursuit of rigorous questions about aesthetics, production, distribution, or audiences. The Head of Research and Scholarship at the BFI, and the Lead Curator for Moving Image and Curator for Popular Music at the British Library agreed that this situation needed to be addressed.

Academic interest in analysis of these hidden industries was emerging (e.g. Grainge and Johnson, 2015), but published documentation was still limited, with the exception of Fletcher's rich account of British advertising (2008). Non-academic research focused on distribution (Banks, 1996; Denisoff, 1987), the USA (Austerlitz, 2008; Schwartz, 2007), or directors and textual analyses rather than industry studies (Aust \& Kothenschulte, 2011). Significant research by Donnelly (2007), Railton \& Watson (2011), and Vernallis (2001, 2002, 2004, 2007, 2008, 2013a, 2013b), demonstrated the urgent need for evidenced-based understanding of the production of music videos. The intention of our research project was to redress that using Keith Negus's pioneering work on the music industry as a culture of production $(1992,1997,1999)$ and his later work on creativity (Negus \& Pickering, 2004). Drawing additionally on Caldwell's work on production cultures (2008, 2014) and his concept of 'industry intellectuals' (2009), we were keen to employ sociological and ethnographic approaches to the study of art and culture (Bechky, 2006; Born, 2004, 2010; Hesmondhalgh, 2007; Hesmondhalgh \& Baker, 2011). We intended to identify the distinctive and unusual characteristics of music video as a hybrid production culture emergent from the fusion of graphic design (album cover design), portrait photography, television live concert performance, and fine art that emerged in the highly vibrant art school culture of the late 1960s which has had a profound, widespread, but as yet undocumented impact on the wider arts economy and culture of Britain.

In 2013, Carol Vernallis called for a canon of music video (2013a). This special issue reflects research that has been undertaken by our partners in a larger research process centred on understanding how to tell a coherent story about an industry that has produced a huge number of music videos, the very definition of a 'music video', how to curate 'music video' for the general public, and how to advise the BFI and British Library on a collections policy for music video as cultural screen heritage. Within this journal issue, several of the contributors have chosen to refer to music videos as 'promos' and the industry as the 'promo industry', for example. However, the term used within the industry itself is 'music video'. There are many different music genres and music communities, and each holds a different set of criteria about what constitutes a 'great' music video. The kind of video that worked in 
Emily Caston and Justin Smith • Introduction

Sheffield in the early 1990s wasn't right for the Madchester scene at that time, and the kind of video that works for Radiohead isn't the kind of video that works for One Direction's fan-base or Coil's. And, in an age in which most of the music videos generating income for British labels are the unofficial fan mash-ups, remixes, and lyric videos on YouTube (yielding advertising revenue for the labels), what does the term 'music video' actually mean? Which of these works is a music video and which is not? From one point of view, in order to include current YouTube content, a music video is nothing more than a video edited to music, with the concept of 'cut' being applied in the loosest of senses. But because, in the professional music video production industry, a number of editors today are re-mixing the audio track to make it support the visual track, even this admits of exclusions (examples are Hurts' 'Lights' [2015] and The Shoes' 'Time to Dance' [2012]). The result is that canon formation is not only impossible, but undesirable. Exactly what the significance of music video is within British screen and music heritage remains to be seen because so many of the works are still being uncovered. In August 2015, we identified that the Camden base of MTV held 90,000 broadcast masters of videos. We know that the VPL's 2015 database of music videos licensed for broadcast in the UK contains 24,037 physical or digital video holdings, and that their total database of videos licensed for broadcast in the UK is in the region of 300,000 , a figure which would include many US videos broadcast in the UK. We estimate that the number of 'British music videos' commissioned in the UK since 1965 has been close to 200,000. From this wonderful and rich cultural history, it would be both impossible and unproductive to select any closed canon.

Rather, we have tried to suggest some internal and relevant criteria by which future researchers and students of music video might want to investigate this rich heritage in future. For ourselves, understanding the number of videos that are currently 'at risk', we have focused on a number of lists. The first, addressed by Dylan Cave, comprises works which represent landmarks in technical innovation, film style and genre, or landmarks in terms of production method, distribution, or exhibition. This collection of 100 videos will be donated to the BFI. A second collection, which we have called 'the untold story of British video' is a larger DVD collection to be distributed by Thunderbird Releasing, containing videos which are lesser known in the public eye, but nevertheless highly significant within the industry and to particular British music communities and audiences. For the British Council, we are creating a collection of British music videos containing landmark choreography, or dance styles and cinematography. A 'great' video in the age of the internet, is not a 'great' video in the 'golden age' of British music videos 
because audiences hold different expectations, and commissioners are managing different budgets.

The articles collected here reflect the first stage of our research and our focus on the 1980s to the present day, and one of the important points we want to counter in this collection is the widespread (mistaken) view that music videos were shot on video tape. In the 1960s, most music videos were shot on $16 \mathrm{~mm}$. The videos for Eric Burdon and the Rolling Stones created by Peter Whitehead, for example, were shot by him as the cinematographer on $16 \mathrm{~mm}$ and edited on $16 \mathrm{~mm}$. In the $1970 \mathrm{~s}$, most videos were still shot on $16 \mathrm{~mm}$, although some were created in $35 \mathrm{~mm}$ and a lesser number - towards the late 1970s - originated on video tape (Queen's 'Bohemian Rhapsody', 1975, is a case in point). In the early $1980 \mathrm{~s}$ as budgets rose, most directors moved to $35 \mathrm{~mm}$ (in his book Egg $n$ Chips \& Billie fean, Steve Barron says that the video he directed for the Human League's 'Don't You Want Me' [1981] was one of the first to be shot on $35 \mathrm{~mm}$ ). If artists couldn't afford $35 \mathrm{~mm}$, as with Ultravox in the making of 'Vienna', they used every in-camera and post-production technique to make the video look like $35 \mathrm{~mm}$. Released in 1981, 'Vienna' was shot on a paltry budget of under $£ 7,000$ because Chrysalis were not willing to fund the video. Bowie's 'Ashes To Ashes' video (1980) by contrast, secured an all-time high budget from his label of $£ 250,000$. Although 'Ashes To Ashes' was shot on $16 \mathrm{~mm}$, his next video was shot on $35 \mathrm{~mm}$. Throughout the $1990 \mathrm{~s}$, directors shot on $35 \mathrm{~mm}$ or, as from 1987 when budgets started to fall, $16 \mathrm{~mm}$. In general, a video for an international artist targeted at the US market would be budgeted to shoot on $35 \mathrm{~mm}$, and a lower budget video for an artist with a UK or European market would be shot on $16 \mathrm{~mm}$. The scene changed with the introduction of digital cinematography in the early 2000s. Directors and cinematographers, like their peers in cinema, were initially very reluctant to drop $35 \mathrm{~mm}$ in favour of digital, but by the mid 2000s probably less than a quarter of UK videos were being shot on digital. When UK-based film laboratories ceased to process $16 \mathrm{~mm}$ in the early 2010s, low-budget productions had few options but to move to digital. Today, most videos are shot on digital, although some DPs (Directors of Photography) and directors remain committed to $35 \mathrm{~mm}$ as a superior format, or as the aesthetically appropriate format for certain video concepts. The history of cinematography in British music video has yet to be written, but is a fascinating one containing myriad insights into technological and artistic innovations and experiments. It is also where many now internationally acclaimed British cinematographers such as Seamus McGarvey, John Mathieson, Dan Landin, and Robbie Ryan began their careers and learned their craft. 
Emily Caston and Justin Smith - Introduction

This journal special issue, then, does not aim to provide a comprehensive overview of British music video nor address the myriad of fascinating research questions. It presents the most significant of our research findings from the first year of the project. It concentrates on the period since 1980, a landmark year in which Bowie released his iconic 'Ashes To Ashes' video directed by David Mallet. As we were drafting the articles in this publication, evaluations of Bowie's impact on music were pouring in. It was immediately obviously that Bowie's impact on film, image, fashion, and gender in British music video cannot be underestimated and warrants probably a whole journal issue in itself.

In his article, Justin Smith considers British music video on television, with a focus on The Chart Show, established by Keith Macmillan first on Channel 4 (1986-1988) and then ITV (1989-1998). The original presenterless music show, it offered a radically different take on new releases from the BBC's long-running Top of the Pops, and was equally distinct from (if inspired by) MTV. The Chart Show not only inaugurated a Saturday morning television ritual for teenagers in households across the UK, but it also shaped production flows and release windows for the industry. Whilst its prized 'exclusives' became as famous as its computer graphics, behind-the-scenes legal disputes were as instrumental in establishing the commercial value and status of music video as television content, as the show's format was expanding the aesthetic dimensions of the pop promo across a range of music genres. Beginning at a time when MTV was still unavailable in the UK, The Chart Show was innovatory in consolidating music video as the lingua franca of the pop singles market. Drawing on archival sources from Channel 4, and the trade and popular music presses, this article shows how The Chart Show helped shape the form of music video, contributed to its commercial status, boosted singles sales, and drove industry demand and production schedules. It argues that an appreciation of music video is dependent upon the historical specificity of its broadcast context.

Emily Caston looks at the pioneering British choreographers in music video from Arlene Philips (founder of Hot Gossip), Kate Bush, and Michael Clark in the 1980s, to the current cutting-edge work of choreographer/ director partnerships such as FKA Twigs and Aaron Sillis, Garth Jennings and Wayne McGregor, and award-winning director/choreographer Holly Blakey. In the first section, Caston presents an overview of the development of genres of dance and choreography in music videos, from the 'loose' choreography of pop acts to the formal, tightly choreographed, routines of those influenced by the Hollywood musical tradition to the street dance video ushered in following Malcolm McLaren's breakthrough 'Buffalo Gals' video (1983). She argues that British music videos should not be 
negatively compared to their bigger budget US counterparts but should instead be appreciated on their own merits - and factors such as the greater creative exchange with ballet, contemporary dance, experimental film, and narrative film. Caston draws attention to the importance of 'social realism' within British choreographed music videos, and points out that the recent work of Matthew Bourne and FKA Twigs overrides the traditional distinction between 'dance film' and commercial music dance film.

The BFI's Will Fowler focuses on the fertile intersection between experimental film, radical television, and music video in the 1980s. There is a long history of relations between avant-garde film and the pop promo dating back to Peter Whitehead and Anthony Stern in the 1960s, but British art schools produced a generation of experimental filmmakers who embraced aspects of the UK's vibrant post-punk indie music scene in the $1980 \mathrm{~s}$ and visualised it in daring and imaginative ways. This article provides a new exploration of the British underground film scene and its influence on, and relationship with, pop video tropes and techniques, and MTV. It considers the rich sub-cultural interrelations of the early $1980 \mathrm{~s}$ that embraced esoteric ideas, queer occultism, punk, postmodernism, British art schools, Derek Jarman, William Burroughs, home video, Scratch Video, Video Nasties, Super 8, Michael Jackson, Grayson Perry, John Maybury, the Avebury Ring, Duran Duran, MerleauPonty, Dr John Dee, Jean Cocteau, and Neneh Cherry. Fowler establishes the unique context of film and television culture in the UK at the turn of the 1980s which enabled experimental and underground filmmaking practices to reach a wider audience through innovative programming opportunities at Channel 4 and via the expanding medium of music video. He describes the powerful, exploratory nature of independent film that existed at this time and its basis in British art schools; several of the practitioners subsequently went on to major careers as pop video directors, demonstrating a two-tiered influence on both the industry, and moving image aesthetics over the next 20 years.

Dylan Cave, another of the BFI National Archive's curatorial team, outlines the various curatorial approaches to its collection which reveal the archive's music video riches, including details about the 'British Landmark Video' collection, curated as part of the 'Fifty Years of British Music Video' project. Cave situates his curatorial work in the broader context of the politics of traditional approaches to canon formation, of which the research partners in this project have been critical and keen to avoid. Cave raises important questions about critical approaches to music video and the contested terminology of its classification. Pop promos combine the commercial and artistic extremes of moving image production, 
capturing and expressing cutting-edge contemporary attitudes in succinct and stylish ways. They have been an integral part of the British moving image industry since music video became a viable industry in the early 1980s, yet their place in British film and moving image history remains largely unsung. He looks at alternative ways for the BFI to collect music videos given that organisations such as the BFI and British Library cannot receive an unlimited number of donations. By necessity, even in the age of seemingly unlimited 'digital storage', moving image archives have to be selective in their acquisition and curatorial procedures, not only because unlimited digital storage comes at a price, but also because of the cost of cataloguing individual works. This has involved a careful consultation with our industry panel of directors, producers, and commissioners about which videos constitute 'landmark' breakthroughs in video techniques, styles, genres, or business practices.

This issue is concluded with a transcribed extract (edited by Emily Caston) from a specially-commissioned focus group on editing in British music video, featuring contributions from directors and editors working in the UK and Ireland. From a filmmaking perspective, music video is arguably foremost an editor's medium. Yet the development and diversity of the editor's craft has been obscured in academic discourse by reductive arguments about the impact of MTV (centred chiefly around pace of editing). This focus group transcript reveals a much more complex and self-reflexive picture, foregrounding practitioners' own discourse about editing styles and technologies in a wide-ranging and lively discussion. The integrity of the editor's work in music video has often been compromised by relationships with directors, commissioners, and record labels, to the extent that it is necessary to disentangle the network of practices at the level of production and post-production in order to recognise the primacy of editing at the cutting edge between sound and image. This transcript further demonstrates that in order to advance the academic field in music video studies it is necessary to engage with the industry at large, and to record and interpret the personal testimony its major creative talents. The invaluable co-operation of this generous, intellectual creative community has made this research possible, and it is to them that we dedicate this work.

This article was published open access under a CC BY license https://creativecommons.org/licenses/by/4.0/ 


\section{References}

Aust, Michael P. \& Kothenschulte, Daniel (2011) The Art of the Pop Video. Koln:

Distanz.

Austerlitz, Saul (2008) Money for Nothing: A History of the Music Video from the Beatles to the White Stripes. New York: Continuum.

Banks, Jack (1996) Monopoly Television: MTV's Quest to Control the Music. Colorado: Westview Press.

Barron, Steve (2014) Egg n Chips \& Billie Jean: A Trip Through the Eighties. CreateSpace Independent Publishing Platform.

Bechky, Beth A. (2006) 'Gaffers, Gofers, and Grips: Role-Based Coordination in Temporary Organizations', Organization Science, 17 (1), pp.3-12.

Born, Georgina (2004) Uncertain Vision: Birt, Dyke and the Reinvention of the BBC. London: Secker \& Warburg.

Born, Georgina (2010) 'The social and the aesthetic: for a post-Bourdieuian theory of cultural production', Cultural Sociology, 4(2), pp.171-208.

Caldwell, John Thornton (2008) Production Culture: Industrial Reflexivity and Critical Practice in Film and Television. Durham and London: Duke University Press.

Caldwell, John Thornton (2009) "Both Sides of the Fence": Blurred Distinctions in Scholarship and Production (a Portfolio of Interviews)'. In: Mayer, Vicky, Banks, Miranda J \& Caldwell, John T. (eds). Production Studies: Cultural Studies of Media Industries. New York: Routledge, pp.214-216.

Caldwell, John Thornton (2014) 'Para-Industry, Shadow Academy', Cultural Studies, 28 (4), pp.720-740.

Caston, Emily, Parti, Nisha, Walker, Nijico \& Sutton, Carrie (2000) 'Report on the Music Video Industry in 1998 and 1999', Promo, April, pp.6-7.

Denisoff, R. Serge (1987) Inside MTV. New Brunswick: Transaction Publishers.

Donnelly, Kevin (2007) 'Experimental Music Video and Television'. In: Mulvey, Laura \& Sexton, Jamie (eds). Experimental British Television. Manchester:

Manchester University Press, pp.166-179.

Fletcher, Winston (2008) Powers of Persuasion: The Inside Story of British Advertising. Oxford: Oxford University Press.

Grainge, Paul \& Johnson, Catherine (2015) Promotional Screen Industries. London and New York: Routledge.

Hesmondhalgh, David (2007) The Cultural Industries. London: Sage.

Hesmondhalgh, David (2014) 'The Menace of Instrumentalism in Media Industries Research and Education', Media Industries fournal, 1 (1), pp.21-26.

Hesmondhalgh, David \& Baker, Sarah (2011) Creative Labour: Media Work in Three Cultural Industries. Abingdon, Oxon: Routledge.

Hutton, Will, O’Keeffe, Áine, Schneider, Phillipe, Andari, Robert \& Bakhshi, 
Hasan (2007) Staying Ahead: The Economic Performance of the UK's Creative Industries. London: DGMS.

Mayer, Vicky, Banks, Miranda J., \& Caldwell, John T. (eds) (2009) Production Studies: Cultural Studies of Media Industries. New York: Routledge.

Negus, Keith (1992) Producing Pop: Culture and Conflict in the Popular Music Industry, New York: Oxford University Press.

Negus, Keith (1997) 'The Production of Culture'. In: Du Gay, Paul (ed.). Production of Culture / Cultures of Production. London: Sage Publications, pp.67-118.

Negus, Keith (1999) Music Genres and Corporate Cultures. London: Routledge.

Negus, Keith \& Pickering, Michael J. (2004) Creativity, Communication and Cultural Value. London: Sage.

Railton, Diane \& Watson, Paul (2011) Music Video and the Politics of Representation. Edinburgh: Edinburgh University Press.

Schwartz, Lara M. (2007) Making Music Videos: Everything You Need to Know from the Best in the Business. New York: Watson-Guptill.

Vernallis, Carol (2001) 'The Kindest Cut: Functions and Meanings of Music Video Editing', Screen, 42 (1), pp.21-48.

Vernallis, Carol (2002) 'The Functions of Lyrics in Music Video', Fournal of Popular Music Studies, 14 (1), pp.11-31.

Vernallis, Carol (2004) Experiencing Music Video: Aesthetics and Cultural Context. New York: Columbia University Press.

Vernallis, Carol (2007) 'Strange People, Weird Objects: The Nature of Narrativity, Character, and Editing in Music Videos'. In: Beebe, Roger \& Middleton, Jason (eds). Medium Cool: Music Videos from Soundies to Cellphones. Durham \& London: Duke University Press, pp.303-328.

Vernallis, Carol (2008) 'Music Video, Songs, Sound: Experience, Technique and Emotion in Eternal Sunshine of the Spotless Mind', Screen, 49 (3), pp.277-297.

Vernallis, Carol (2013a) Unruly Media: YouTube, Music Video and the New Digital Cinema. Oxford: Oxford University Press.

Vernallis, Carol (2013b) 'Music Video's Second Aesthetic?'. In: Richardson, John, Gorbman, Claudia, \& Vernallis, Carol (eds). The Oxford Handbook of New Audiovisual Aesthetics. Oxford: Oxford University Press, pp.437-465.

\section{Media Cited}

'Buffalo Gals' [music video], Malcolm McLaren, Malcolm McLaren, Charisma, UK, 1983.

'Lights' [music video], Hurts, Dawn Shadforth, RGA, UK, 2015.

'Time To Dance' [music video], The Shoes, Daniel Wolfe, Green United Music, UK/FR, 2012. 